\title{
UTOPIA ANALIS KEBIJAKAN DALAM ORGANISASI PEMERINTAH
}

\author{
Erna Noviyanti \\ Lembaga Administrasi Negara \\ Agit Kristiana \\ Lembaga Administrasi Negara
}

\begin{abstract}
Abstrak
Profesi analis kebijakan di lingkungan pemerintah Indonesia lahir sebagai respon terhadap berbagai masalah dan kontroversi kebijakan publik di Indonesia. Setelah berjalan dalam kurun waktu \pm 3 (tiga) tahun, eksistensi dan peran Analis Kebijakan (AK) belum menampakan geliat dan kiprahnya di instansi masing-masing. Pusat Pembinaan Analis Kebijakan (PUSAKA) melakukan sebuah mini research dengan tiga dimensi dalam Human Capital (organisasi, kepemimpinan, dan kapasitas) untuk melihat peran dan utilisasi AK. Mini research tersebut menghasilkan temuan bahwa rata-rata K/L/Pemda belum siap dalam mendukung kinerja AK. Dalam 3 (tiga) dimensi tersebut dimensi organisasi memiliki nilai terendah, meskipun dimensi yang lain juga belum mencapai kondisi ideal. Permasalahan tersebut perlu ditindaklanjuti oleh LAN dengan mengembangkan strategi baru untuk meningkatkan utilisasi ini, seperti pengembangan strategi baru dalam advokasi JFAK. Selain itu peran Kementerian Pendayagunaan Aparatur Negara dan Reformasi Birokrasi (MENPAN RB) juga dibutuhkan untuk mendorong utilisasi di K/L/Pemda. Upaya perbaikan tersebut juga harus didukung dengan keterlibatan $\mathrm{K} / \mathrm{L} / \mathrm{Pemda}$ untuk memanfaatkan potensi $\mathrm{AK}$ dalam proses kebijakan di instansi masing-masing.
\end{abstract}

Kata kunci: utilisasi analis kebijakan, modal sumber daya manusia

\begin{abstract}
Policy analyst profession in the Indonesian government is established as a response to various issues and controversy of public policy in Indonesia. After 3 (three) years of implementation, the existence and role of policy analysts in their respective agencies have not demonstrated meaningful performance as intended. The Center for Policy Analyst Development (PUSAKA) undertook mini research looking at three-dimensional aspects in Human Capital (organization, leadership, and capacity) to see the role and utilization of policy analyst. This mini research resulted in the finding that typically, Ministries/Agencies/Local Governments were not ready to support the performance of policy analyst. Among 3 (three) dimensions, the organizational dimension scored the lowest, similarly other dimensions have not reached optimum level. These issues need to be acted upon by NIPA by developing new strategies to improve policy analyst utilization, such as developing new strategies in advocating policy analyst profession. In addition the role of the Ministry of State Apparatus Empowerement and Bureaucratic Reform (MENPAN RB) is important to encourage policy analyst utilization in Ministries/Agencies/Local Governments. The improvement require support trough involvement of Ministries/Agencies/LGs to maximize the potential of policy analysts in the policy process in their respective agencies.
\end{abstract}

Keywords: policy analyst utilization, human capital 


\section{Latar Belakang}

Jabatan Fungsional Analis Kebijakan (JFAK) sebagai sebuah jabatan fungsional yang baru lahir pada tahun 2013, memberikan sebuah harapan baru bagi tumbuhnya atmosfer kebijakan publik di Indonesia yang lebih baik dan memberikan manfaat yang besar bagi kepentingan publik. Kebijakan yang baik adalah kebijakan yang tidak hanya didasari oleh intuisi, opini, dan kepentingan sektoral para pengambil keputusan.

Setelah berjalan dalam kurun waktu \pm 3 (tiga) tahun PUSAKA sebagai unit yang secara fungsional mempunyai tugas melahirkan dan membina Analis-analis Kebijakan ini, berhasil merekomendasikan sejumlah AK di Kementerian/Lembaga/ Pemda.

Sebagai sebuah profesi yang baru berkembang, profesi analis kebijakan di lingkungan organisasi pemerintahan di Indonesia belum cukup dikenal luas atau bahkan masih dianggap kurang penting dibandingkan dengan jabatan fungsional yang sudah ada selama ini.

Sampai dengan saat ini terdapat 73 orang pemangku jabatan fungsional ini yang tersebar di berbagai Kementerian/ Lembaga/Pemda. Analis kebijakan tersebut direkrut melalui inpassing dan pengangkatan pertama.

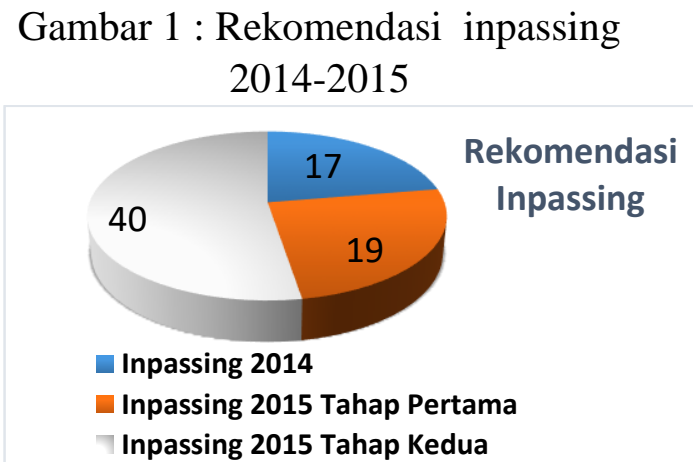

Sumber : Pusat Pembinaan Analis

Kebijakan (2015)
Gambar 2 : Rekomendasi pengangkatan pertama 2014-2015

Jumlah Rekomendasi

Pengangkatan Pertama

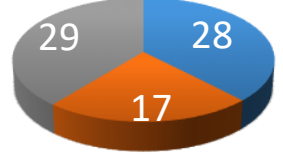

- Pengangkatan Pertama (Pilot Project)

- Pengangkatan Pertama 2015

- Pengangkatan Pertama 2016

Sumber : Pusat Pembinaan Analis Kebijakan (2016)

Sebaran data JFAK per November 2016 dominan berada di K/L (Pusat) sebanyak 66 AK (86\%) dan sisanya 7 AK (14\%) berada di daerah.

Gambar 3: Sebaran Analis Kebijakan di Indonesia

SEBARAN ANALIS KEBIJAKAN
DI INDONESIA

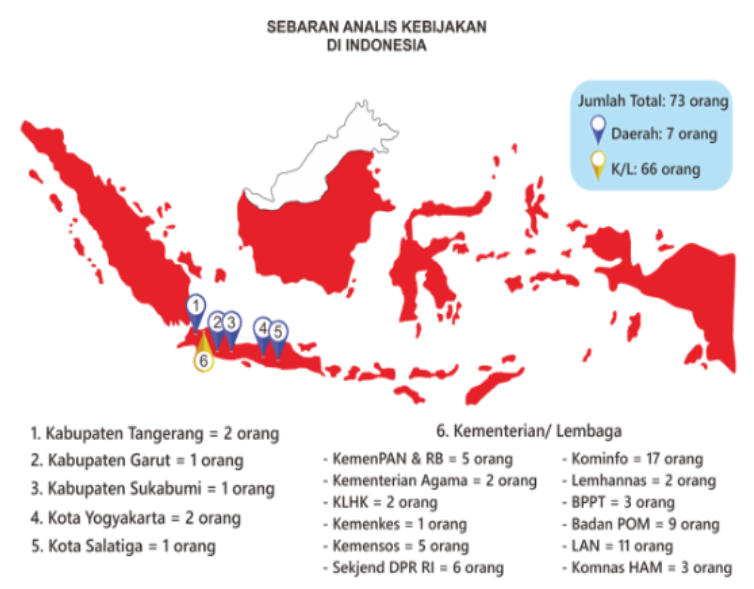

Sumber : Pusat Pembinaan Analis Kebijakan (2016)

Keberadaan para AK diharapkan memberikan kontribusi signifikan terhadap kinerja organisasi di K/L/Pemda. Namun demikian eksistensi AK ini belum banyak diketahui terutama dalam menjalankan perannya sebagai policy developer dan adviser. PUSAKA melakukan mini research dengan pendekatan human capital untuk melihat utilisasi $\mathrm{AK}$ melalui tiga dimensi analisis yang meliputi dimensi organisasi, kepemimpinan dan kapasitas AK. 


\section{Utilisasi Analis Kebijakan}

Tuntutan terhadap keberadaan kebijakan publik yang berkualitas dan berdasar pada evidence based merupakan salah satu tantangan yang dihadapi oleh para AK. Analis kebijakan diharapkan dapat memperbaiki kualitas kebijakan secara signifikan dan berkelanjutan.

Berdasarkan konsep strategic alignment, setiap proses rekrutmen pegawai harus didasarkan pada kebutuhan organisasi. Pegawai tersebut harus berkontribusi dan memberikan manfaat bagi organisasi. Kondisi ideal ini dapat dicapai bila pegawai tersebut diposisikan sebagai capital. Human Capital Management adalah upaya untuk mengelola dan mengembangkan kemampuan manusia untuk mencapai tingkat signifikan yang lebih tinggi secara kinerjanya (Chatzke, 2004).

Dalam konsep human capital, dipersyaratkan adanya dukungan baik dari organisasi, kepemimpinan dan kapasitas terhadap masing-masing pegawai. Pada konteks identifikasi utilisasi JFAK, peran AK ini juga tidak hanya tergantung dari kapasitas AK itu sendiri, namun juga dari dimensi organisasi, dan kepemimpinan.

Gambar 4 : Konsep Utilisasi JFAK dalam Human Capital Theory

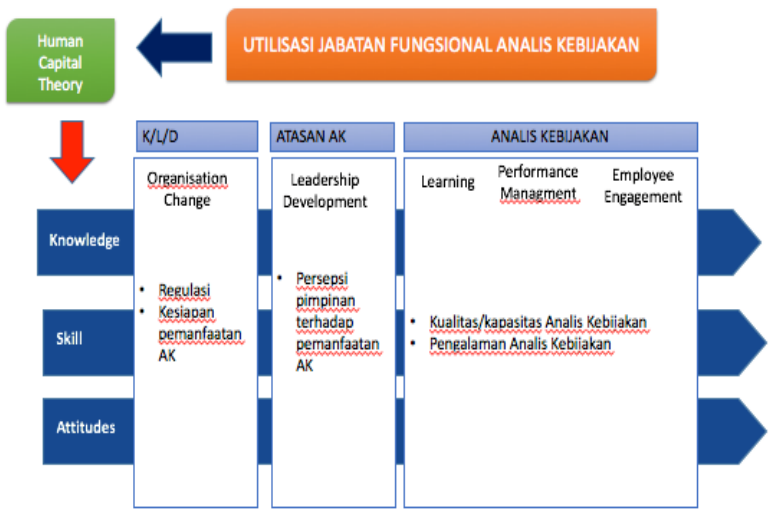

Sumber : diadaptasi dari Lacy, Arnott, dan Lowitt (2009)
Berdasarkan data lapangan yang diperoleh dari 16 (enam belas) lokus penelitian yang terdiri dari 5 (lima) kementerian, 6 (lembaga) dan 5 (lima) pemerintah daerah yang memiliki AK, berikut adalah hasil temuan lapangan:

\section{Dimensi Organisasi}

Salah satu dimensi dalam human capital adalah dimensi organisasi, yang dilihat pada keberadaan regulasi yang mengatur tentang pemanfaatan AK dan kesiapan organisasi dalam memanfaatkan AK. Berikut adalah gambaran nilai dimensi organisasi pada lokus penelitian.

Gambar 5 : Nilai Dimensi Organisasi

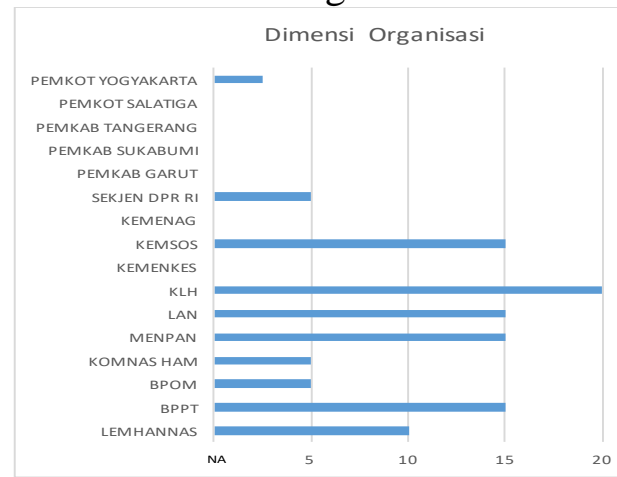

Pada gambar di atas dapat dilihat sebaran nilai $\mathrm{K} / \mathrm{L} / \mathrm{Pemda}$ pada dimensi organisasi. Nilai rata-rata 10,75 (masuk dalam kategori tidak siap), dengan nilai tertinggi 20 (KLH), dan nilai terendah 2,5 (Pemkot Yogyakarta). Informasi lain yang diperoleh dari dimensi organisasi adalah:

a. Regulasi yang mengatur tentang pemanfaatan AK

Beberapa K/L/Pemda tidak memiliki dokumen peta jabatan, anjab, dan ABK karena JFAK merupakan jabatan baru. Sehingga dasar penyusunan formasi JFAK hanya pada surat edaran LAN.

b. Kesiapan organisasi dalam memanfaatkan AK

- Beberapa K/L/Pemda tidak memiliki dokumen SOP 
- Beberapa K/L/Pemda tidak memiliki kebijakan teknis tentang JFAK,

- Pemahaman spesisfik tentang pengelolaan JFAK masih terbatas terutama tentang satuan hasil kerja JFAK.

- Penempatan pemangku JFAK tidak berdasarkan kebutuhan organisasi dan kepakaran (sebagai akibat tidak memiliki dokumen peta jabatan).

\section{Dimensi Kepemimpinan}

Dimensi kedua adalah kepemimpinan, dimensi ini melihat persepsi pimpinan organisasi terhadap pemanfaatan JFAK. Berikut adalah gambar sebaran nilai dimensi kepemimpinan pada lokus penelitian.

Gambar 6 : Dimensi Kepemimpinan Dimensi Kepemimpinan

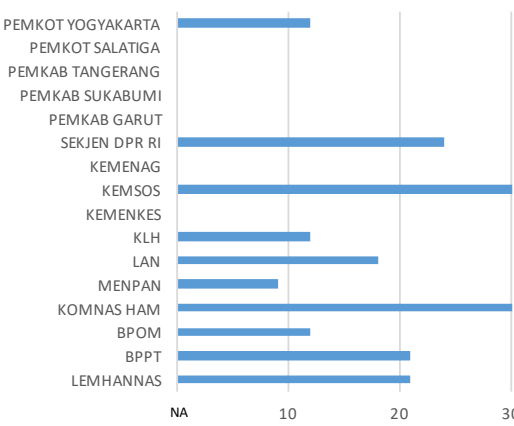

Pada gambar di atas dapat dilihat nilai rata-rata adalah 18,19 (masuk dalam kategori tidak siap) dengan nilai tertinggi sebesar 30 (Kemsos), dan nilai terendah sebesar 9 (Menpan). Pada temuan di lapangan menemukan bahwa sebagian besar pimpinan belum memahami peran dan fungsi JFAK secara utuh, dimana mereka cenderung mengalami kebingungan dalam memanfaatkan hasil kerja AK. Dampak dari kurangnya pemahaman tersebut adalah kurangnya dukungan pimpinan terhadap AK.

\section{Dimensi Kapasitas AK}

Untuk melihat dimensi kapasitas AK, dalam penelitian ini difokuskan pada indikator kualitas/kapasitas dan pengalaman pemanfaatan AK. Berikut adalah gambaran sebaran nilai dimensi kapasitas AK pada lokus penelitian.

Gambar 7 : Dimensi Kapasitas

JFAK

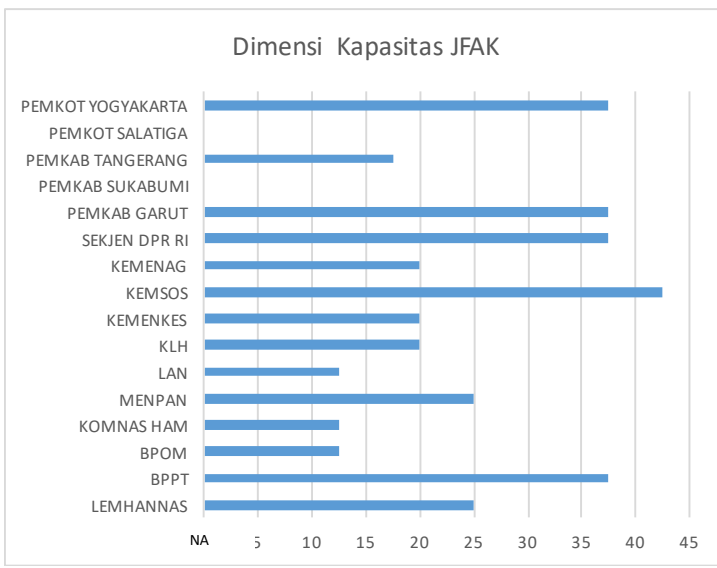

Pada gambar di atas dapat diihat sebaran nilai dimensi kapasitas JFAK. Dari lokus penelitian tersebut nilai rata-rata 35,75 (masuk dalam kategori tidak siap) dengan nilai tertinggi 42,5 (Kemsos), dan nilai terendah 12,5 (BPOM, KomnasHAM, LAN). Beberapa informasi lain yang diperoleh dalam dimensi ini antara lain:

\section{a. Kualitas/kapasitas AK}

- Sebagian besar JFAK sudah memahami peran dan fungsi jabatannya namun masih belum memahami satuan hasil kerja AK.

- Sebagian besar AK juga belum maksimal dalam melakukan advokasi kebijakan.

\section{b. Pengalaman pemanfaatan AK}

Secara umum para AK sudah dilibatkan dalam pembuatan kebijakan akan tetapi belum maksimal keterlibatannya. Misalnya dilibatkan sebagai anggota tim, namun hasil rekomendasi tidak dijadikan sebagai rujukan kebijakan. 
Berikut gambaran kesiapan organisasi dilihat dari tiga dimensi sebagaimana dijelaskan di atas.

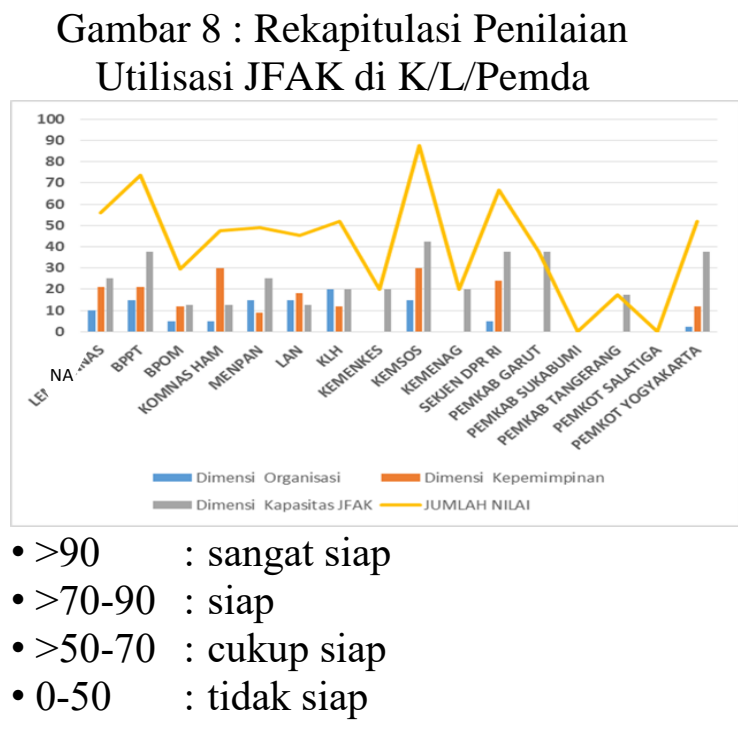

Grafik di atas memperlihatkan sebagian besar lokus penelitian berada dalam kondisi tidak siap (50\%), cukup siap $(25 \%)$ dan kategori siap $(12,5 \%)$. Selain itu masih terdapat $12,5 \%$ tidak memberikan keterangan apapun (Pemkab Sukabumi dan Pemkot Salatiga).

Rata-rata secara keseluruhan hasil penilaian utilisasi JFAK di K/L/Pemda menunjukkan angka 40,87 masuk dalam kategori tidak siap. Kementerian Sosial mendapat skor tertinggi 87,5 dan Pemerintah Kabupaten Tangerang mendapat skor terendah 17,5.

\section{Rekomendasi}

1. LAN yang salah satunya memiliki fungsi dalam advokasi AK, perlu mengembangkan strategi baru dalam dimensi organisasi, misalnya:

- sosialisasi cara penghitungan kebutuhan/ formasi AK,

- sosialisasi tentang peran dan fungsi JFAK dalam organisasi.

2. Kementerian PAN dan RB membuat surat edaran ke K/L/Pemda untuk memperkuat peran AK dalam posisi- posisi kunci proses kebijakan publik di instansi masing-masing.

3. Kementerian/Lembaga/Pemda melakukan transformasi budaya dalam proses perumusan kebijakan, serta penyiapan berbagai "infrastruktur keberadaan $\mathrm{AK}$ di K/L/Pemda".

\section{Referensi}

\section{Buku}

Chatzkel JL, 2004, Human Capital: The rules of engagement are changing, Lifelong Learning in Europe.

Kearns, P, 2005, Human Capital Management, Reed Business Information, Sutton, Surrey.

Nugroho, Riant. 2014. Kebijakan Publik. Jakarta: Gramedia.

\section{Artikel}

Mayo, A., 2000. "The Role of Employee Development in The Growth of Intellectual Capital", Personal Review, Vol. 29, No. 4. http://www. emerald-library.com

Peter Lacy, James Arnott \& Eric Lowitt (2009), "The Challenge of integrating sustainability into talent and organization strategies: investing in the knowledge, Skills and attitudes to achieve high performance", Corporate Governance, 9(4), 484-494.

Pusat Pembinaan Analis Kebijakan. 2015. Statistik JFAK. File diunduh di www.pusaka.lan.go.id/km

\section{Peraturan Perundangan}

Peraturan Menteri Pendayagunaan Aparatur Negara dan Reformasi Birokrasi Nomor 45 Tahun 2013 Jabatan Fungsional Analis Kebijakan dan Angka Kreditnya. 4 November 2013. Berita Negara Republik Indonesia Tahun 2013 Nomor 1342. Jakarta. 